\title{
Aesthetic Paradigm of Art: a Role in Shaping Human Future
}

\author{
Semenova Maria Aleksandrovna ${ }^{1}$, Bykovskaya Maria Alexandrovna ${ }^{2}$ \\ Moscow City University, 4-1 Vtoroy Selskohoziajstvenny proezd, Moscow, Russia, SemenovaMAL@mgpu.ru \\ Moscow City University, 4-1 Vtoroy Selskohoziajstvenny proezd, Moscow, Russia, Logrichka@yandex.ru
}

\begin{abstract}
In this paper, the authors explain the developed and tested aesthetic paradigm of art. This paradigm allows knowledgeably building effective work on the aesthetic development of children at various levels of their education and taking into account modern trends in education and development of the human future.

On top of that, the structural components of the paradigm have been defined, a summary of each of the components has been given, and the conditions for the effective implementation of the aesthetic paradigm of art have been explained.
\end{abstract}

Keywords: aesthetic development, artistic creativity, aesthetic paradigm of art, art, educational activities.

\section{Introduction}

Present-day trends in social evolution can be abundantly described by such words as globalization and acceleration. As a result, the new state of society has emerged, where the main role belongs to a person of the future who can be characterized with ethical and moral high ground, consciousness and the ability to create.

It would be difficult to underestimate the role of human aesthetic education in the modern information society. Art studies enhance a person aesthetically, and an aesthetically enhanced student carries in his consciousness the understanding of the integrity of the world. Such a person develops his workmanship and personal aptitudes, gradually forming an awareness of the need to contribute to the development of society. 
Aesthetic values are not only criteria for assessing the reality around as they also help to develop the personality of the future by determining the social dimension, asserting the position of life and programming the perspective of development.

Researchers of artistry, teachers, musicians and art workers repeatedly noted that the necessary condition of high quality of public life is the priority in the education of a harmoniously developed personality, the formation of spiritual and moral grounds, aesthetic development, the development of personality in the process of self-improvement.

The foundations of aesthetic development have been laid in childhood and formed throughout life, to a greater extent, by means of art: "The main task of the teacher of fine arts is to educate a person of high spiritual and creative culture, characterized by an active aesthetic perception, or, in other words, a person who can create new things in different fields..." (Semyonova, 2015).

Art has the greatest influence on aesthetic development and development of future human personality: creator and trendsetter (Baumgarten, 1964; Nemensky, 1981; Ovsyannikov, 1984). It was understood that education by means of art is different from mechanical learning of dogmas and that it does not hinder the ability to further creativity, but, on the contrary, develops creative abilities and inspires a true creation.

Recent studies also emphasize the special role of art in aesthetic and spiritual development: "Art provides an opportunity to live such life situations that will give the child an invaluable personal spiritual and creative experience. The lesson can be conducted with different approaches in mind. If we teach children to understand art better, we will teach them to understand themselves better" (Valikzhanina, 2018).

The scope of this study has been defined by the existing contradictions between the vast potential of the existing artistic and methodological experience in the field of aesthetic development of children and its insufficient application in the mass practice of educational institutions: what are the pedagogical conditions for the effectiveness of the aesthetic development of children by means of art?

Our study included the following components:

- Collection of theoretical material and guidance papers in the field of aesthetic development of preschool children by means of art.

- Observations in children's educational organizations.

- Compilation of criteria and levels of aesthetic development of pupils.

The study of the collected materials confirmed the need to define and develop an aesthetic paradigm of art, which would allow properly organize the work on the aesthetic development of children at various stages of their maturity and taking into account modern trends.

The purpose of the study is the theoretical justification, development and pilot verification of the aesthetic paradigm of art. 
The goal of this paper is to find out what influence the aesthetic paradigm of art will have on the formation of the person of the future characterized with ethical and moral high ground, consciousness and the ability to create.

\section{Problematic Area: Theoretical Analysis}

Theoretical basis of the aesthetic paradigm of art was the work in the field of aesthetics and art in the education and development of human personality (Baumgarten, 1964; Nemensky, 1981; Ovsyannikov, 1984; Losev, 1963; Semyonova , 2015; Lange, 2016; Vaitkunas, 1967). Research in Education Science and Methodology (Burovkina, 2011; Dubrovin, 2016; Ignatiev, 2007; Komarova, 2015; Melik-Pashayev, 1982; Miroshkina, 1988). Psychology and Physiology (Arnheim, 1974; Elkonin, 1956; Ignatiev, 1961; Maklakov, 2002; Rubinstein, 2015; Vygotsky, 2000; Wenger, 2016). The value of book graphics in the aesthetic and general development of children was also emphasized by artists (Dekhterev, 1972; Gankina, 1963; Gerchuk, 2016). The conciseness and expressiveness of the images, the depth of description of sentiments, moods and character of the captured moment, the interaction of the literary text and artistic image have a powerful impact on the spiritual, emotional and aesthetic development of the child.

Theoretical and practical recommendations on providing aesthetic education and creative service in the modern educational world of foreign researchers are also relevant for our study (Barb-gall, 2016; Mayesky, 2009).

Based on the results of our work and analysis of methodological literature and the most widespread general education programs, we have developed an aesthetic paradigm of art and defined the main components of the paradigm as follows: cognitive component, practical component, culturological component, personality-oriented component, and synergetic component (Figure 1). 


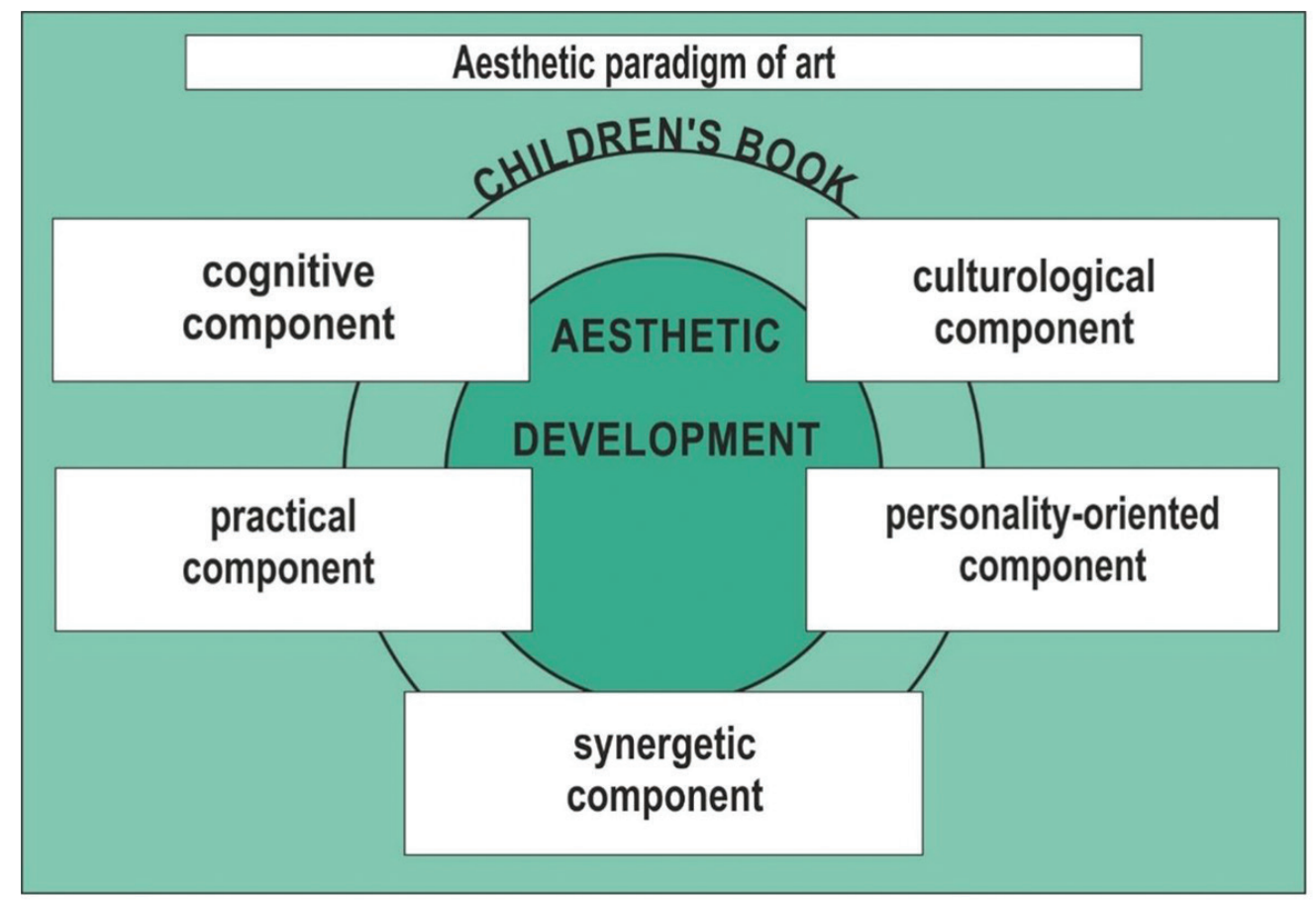

Figure 1. The aesthetic paradigm of art

Let's review it in a greater detail below.

- Cognitive component, included the study of students' art history, the creativity of artists, the specific means of expression of fine arts.

- Practical component, implying the participation of students in various types of art activities related to aesthetic orientation, including fine arts, graphics, book graphics, painting, composition, plein-air painting, project implementation, theater, making scenery, music lessons, etc., and the formation of artistic and visual skills.

- Culturological component, which includes introducing students to the works of art.

- Personal-oriented component, which implies the formation of students' aesthetic preferences, their aesthetic taste, as well as the development of verbal and non-verbal creativity and divergent thinking abilities.

- Synergetic component, entailed the inclusion of various related fields of art, such as music classes, drama and scenery work, museum visits, plein-air painting and others, combined in a unified system of aesthetic development of the child's personality.

All components of the paradigm were interconnected to complement each other. The content of each paradigm component presupposes further filling of the teacher's work plan, defining the main directions of compulsory work on the aesthetic development of students, in view of the generation aspects. 


\section{Materials and Methods}

The aesthetic paradigm of art, as a set of fundamental scientific principles, allows to form a new system of relationships based on spiritual, cultural and aesthetic values.

The aesthetic paradigm of art is aimed at solving educational tasks of the aesthetic kind and includes the following blocks:

- Children's familiarization with aesthetic values/

- Inclusion in active aesthetic activity.

- Development of creative abilities

In our study, we are based on the aesthetic development of children through book graphics.

The study object is the process of aesthetic development of preschool children in artistic and aesthetic interaction with book graphics.

Let's consider the developed paradigm of art and its components on the example of the study in question. Thus, in the cognitive component, there was a replenishment of the luggage of knowledge, artistic images, aesthetic representations in the course of cognitive, game and creative activity.

Taking into account the generation aspects of students, the cognitive component included acquaintance with the genres of fine arts, art history, creativity of artists, the specifics of various means of expression in book graphics, such as line, stain, stroke and color.

The practical component determined the diversity of forms of aesthetic activity organization. The forms of activity used should correspond to the educational purpose, age peculiarities and individual features of children, the specifics of the educational institution, as well as meet modern educational requirements.

These are both organized educational activities, including both traditional theoretical and practical classes and creative variation forms, such as open air, creative workshops, exhibitions, master classes; and project activities; and clubs of additional education; and independent art activities of children. The methodological activities that increase the competence of teachers, like seminars, master classes, open displays and mentoring, have been included in this list.

The practical component also includes the following basic methods of aesthetic development:

- Word methods: storytelling, conversation, reading and discussion.

- Practical methods: game, exercise, practical task and observation.

- Visual methods: displaying works of art, reproductions, illustrations, showing educational presentations and films, examining works of art.

- Problem resolving methods: setting up a problem situation.

- Research method: conducting pilot work. 
The content of the culturological component includes illustrative art and illustrative material for book graphics classes. The works of art selected by the teacher should correspond not only to the tasks of a particular class, but also to the overall goal of aesthetic development. The paradigm determines a number of following requirements for the selection of illustrative material.

- Superb artistic quality of the samples to be shown.

- Compliance with aesthetic canons, notions of beauty.

- Authenticity and recognizability of images.

- Correspondence of the visual material to the generation aspects of the students and cogitability.

- Unity of content and means of expression.

- Harmony of coloristic, tone and compositional solution of the illustrative material.

- Choice of emotional works for illustration.

The personality-centered component involves an individual approach that promotes the formation of aesthetic preferences, aesthetic taste, as well as the development of verbal and non-verbal creativity and divergent thinking abilities. To implement this component, we conducted psychological and pedagogical diagnostics and created an individual educational route for each particular student.

The synergetic component is provided by the unification of the related educational areas into a single space of events, cooperation of teachers, parents of pupils, artists and cultural workers, as well as creation of aesthetic environment.

The implementation of the component above has become the most effective in the context of the educational complex, which includes early childhood educational institutions, schools and clubs of additional education. The practice has shown the importance of organizing the embodiment of the paradigm of art, cooperation with cultural and art institutions and with universities and colleges.

As part of the implementation of the paradigm, aesthetic-oriented activities such as the following have been planned and carried out: "Native Spaces", "cycles of integrated events", "Emotions", "Fairy Tales of the Peoples of the World", "Colored Ocean", "Journey to the Library"; thematic sessions of the Fine Arts Club on introducing children to the works of artists, collections of museums of fine arts, with various techniques of giving the expressive sense of the image; "Fairy Tales and Bylines", "City of Masters", "Fairytale Architecture" and other projects.

Smart perception of works of art is an important condition for the effectiveness of the aesthetic paradigm. In the process of work, it is necessary to focus the attention of students on the main aspects of the artwork, corresponding to the task in solving the illustration: the color, composition, elements of stylization and decoration, means of expressiveness, technical methods and much more. 
The process of demonstration should also be considered, including placement of furniture, lighting, size of illustrative material, application of technical means, such as a projector and interactive whiteboard.

In different types of activity organizations, it is necessary to use certain techniques that contribute to the most effective perception and understanding of works of art. These are methods of comparison, search tasks, analysis of characteristic properties and features of a work, reasoning and game situations.

Children should be able to view works of art in various formats such as reproductions, layouts, books, laid out on the table, placed on the demonstration board, presentations and exhibitions. Visits to museums and art exhibitions should be also noted, as direct acquaintance with works of art makes the perception more intense and emotional.

Impressions are usually consolidated in practice, which can also take various forms: drawing from nature, plein-air painting, sketches, drawing on representation, creating design projects, arts and crafts, etc. (Figure 2).

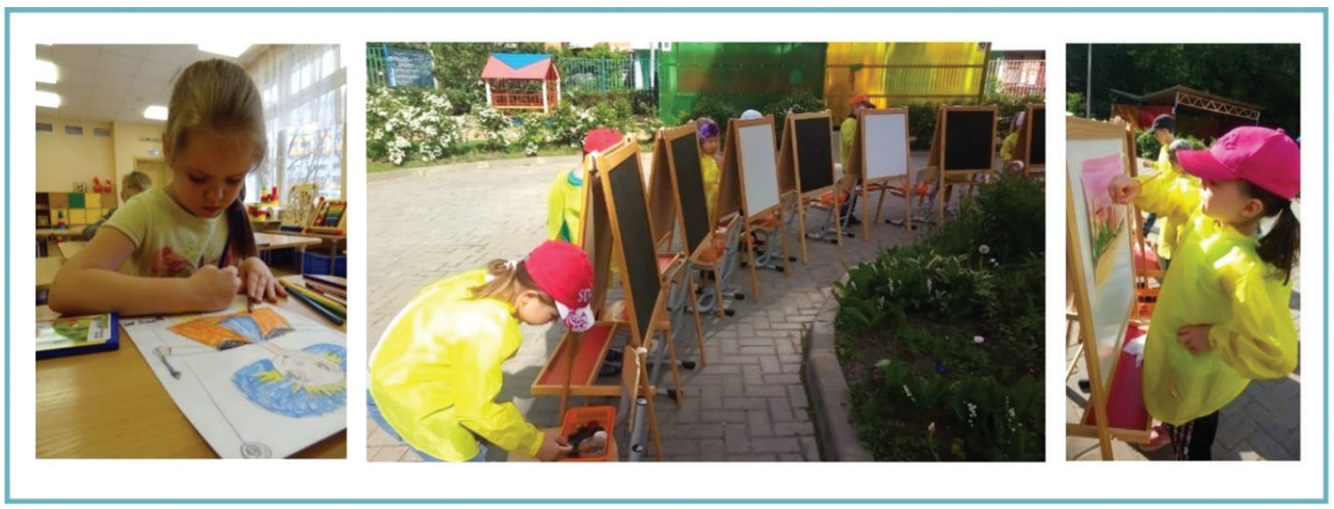

Figure 2. Children 5-6 years. Drawing in the art Studio and in the open air.

A self-reflection is an important phase of activity that develops the skills of self-control, analysis, self-analysis, and critical attitude towards results. And if for early childhood age, reflection of moods, an emotional condition is meant, schoolchildren have access to reflection of activity and the content of educational and developing material.

\section{Findings}

The pilot work included psychological and pedagogical research at the ascertaining stage to reveal the level of aesthetic ideas, verbal and non-verbal creativity and fine arts skills in children. 
In addition, at the formative stage of the study, systems of measures for the aesthetic cycle based on the paradigm of art, have been introduced.

At the control stage of the study, the results of the experiment are analyzed and the data obtained were compared during the ascertaining and forming experiments.

These efforts made it possible to prove a significant growth in the indicators of children's aesthetic development, including the aesthetic perception and developed skills of artistic and creative skills of preschool children.

At the end of the second year of introduction of the paradigm, a cross-section analysis of children's artistic and visual skills was made: pupils were invited to create an illustration for a fairy tale.

The results of the comparative analysis of products of children's artistic activity are presented in the histogram (Figure 3).

Histograms are meant to display the gradation of scales with a maximum of 100 points, take 0 points for a low degree for each percentage, 0.5 points for an average degree for each percentage, and 1 point for a high degree for each percentage.

The histogram clearly shows that the growth rate of artistic and pictorial skills of children of the experimental group is ahead of schedule.

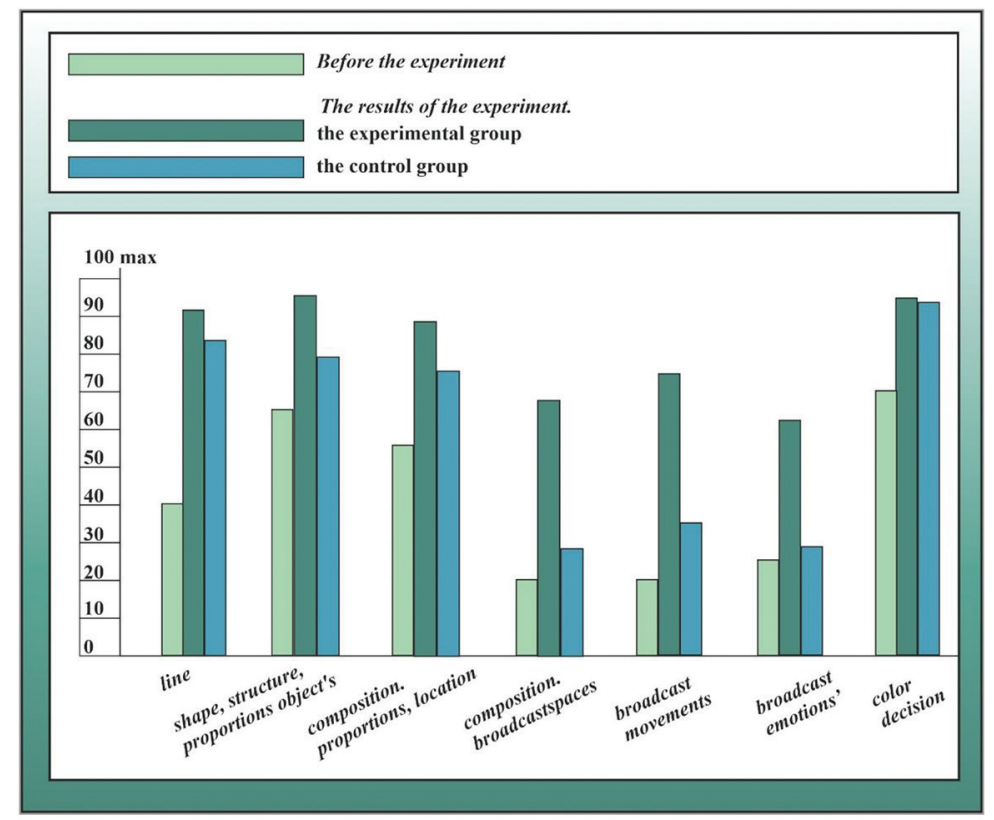

Figure 3: Cross-section analysis of children's artistic and visual skills 
Those artistic and pictorial skills that traditionally cause difficulties, such as giving a sense of space, including the presence of horizon lines, plans, reducing the size of objects in the background, overlapping objects, giving a sense of motion, plastics, character interactions, expression of various emotions of characters in mimic, color, have increased most of the children of the experimental group.

The level of aesthetic representations of the pupils has also significantly increased, which is also confirmed by the findings of the studies, which are reflected in the histogram (Figure 4).

The histogram shows that the values of such indicators as interest in activity and correlation with a literary work have increased insignificantly, as they had rather high indicators initially, and the indicator of emotional response has increased with a slight difference.

Indicators of perception of means of expression and ability to identify significant features have changed more. Obviously, the work performed gave a powerful stimulus to the development of children's aesthetic perception.

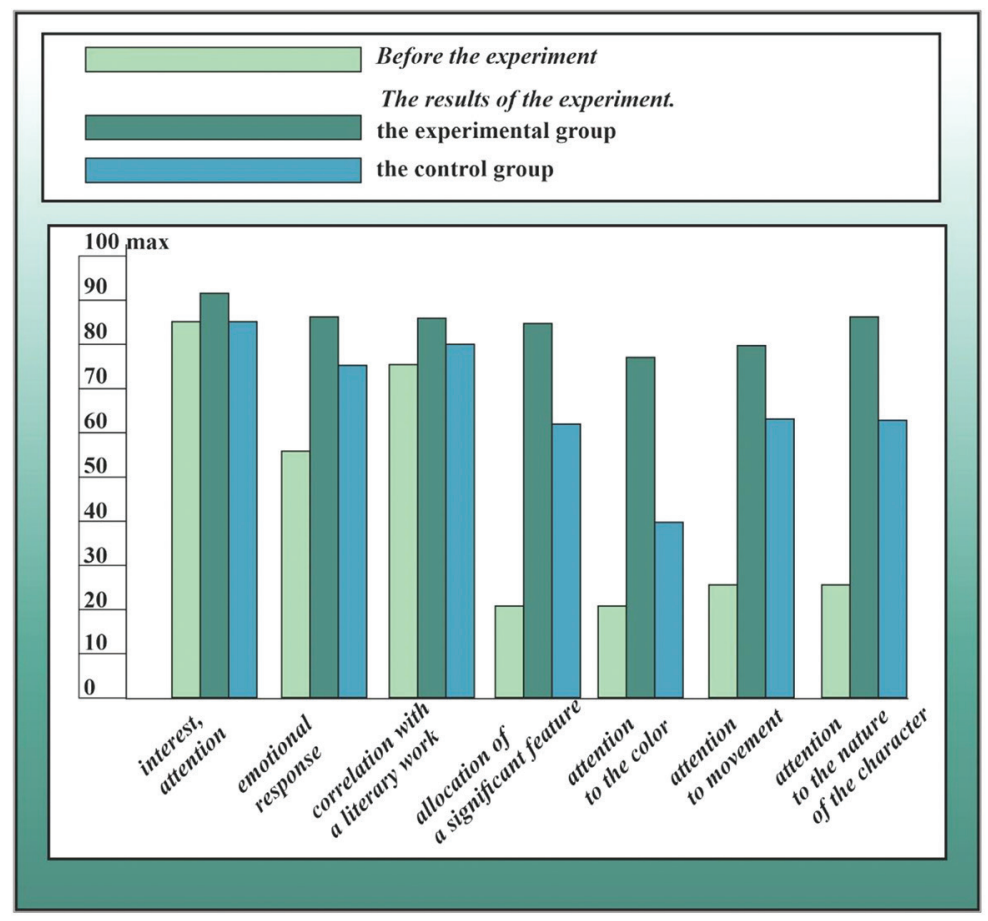

Figure 4: Cross-section analysis of children's aesthetic perceptions 
The diagnosis of verbal and non-verbal creativity of J. Guilford and P. Torrance relies on the four main characteristics of divergent thinking, but dilutes the parameters of verbal and non-verbal parts of creative thinking, which is important for our study.

This test was conducted at both the stating and the control phases, as the most complete reflection of the level of non-verbal creativity. At the ascertaining stage of the experiment, the children with the highest and lowest indicators were identified as requiring special attention and individual approach.

Analysis of test results at the control stage showed that the overall rates of verbal and non-verbal creativity among children has increased. The level of fluency, which characterizes the ability to produce a large number of ideas, as well as the design, which characterizes the ability to develop ideas in detail, has increased the most.

It is important to note that the results of pilot activities have increased not only the level of non-verbal creativity, but also the level of verbal one, despite the absence of a direct task of speech development. Undoubtedly, regular discussions of works of art, conversations and other activities enriched the children's vocabulary, had a beneficial effect on the development of the ability to formulate their thoughts and convert emotional and aesthetic experiences into the verbal plan.

The analysis of works performed by children, observation of their artistic and visual activity, conversations and discussions show that the level of aesthetic development has increased. In particular, the perception of graphic images has become more meaningful, children began to pay attention to details, color, character of lines, to the poses of characters and their facial expressions. On top of that, they have learned to feel the stylistics of the artwork to some extent; children's artistic works have become more diverse in design, full of content, details, etc.

Monitoring children's free activity and the process of classes showed that preschoolers more often used book illustrations as a support for the idea of artistic creation, as a model of artistic expression of images. The children's vocabulary and notions increased. The interest in artistic and visual activities increased significantly. In total, all these indicators expose the effectiveness of introducing the paradigm into the educational process. (Figures 5, 6). 


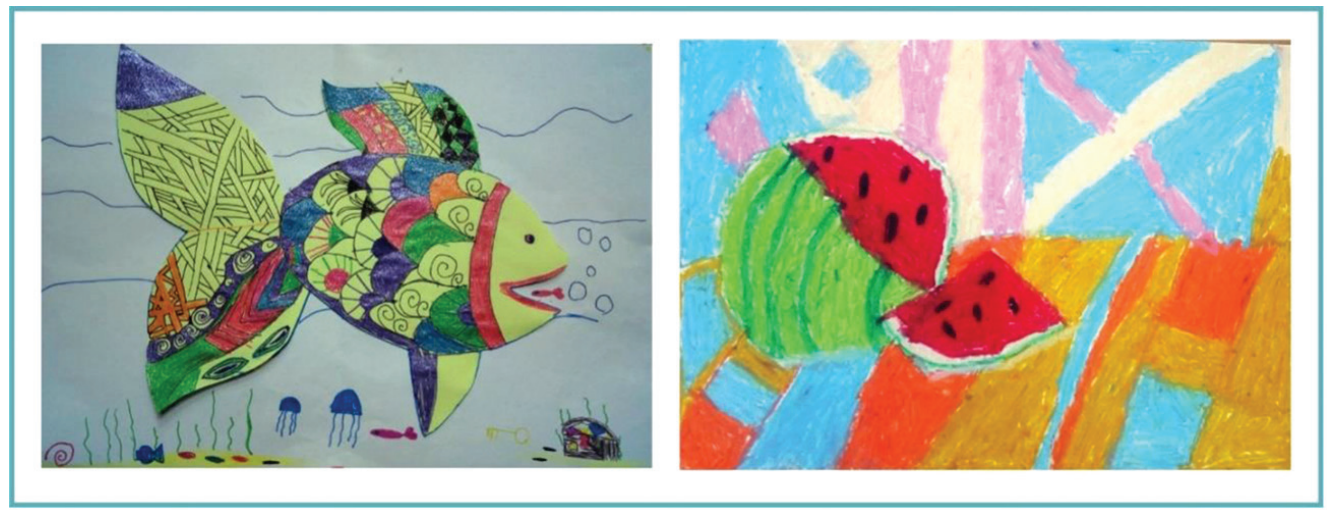

Figure 5. Creative works of children 5-6 years. Colored pens, oil pastels

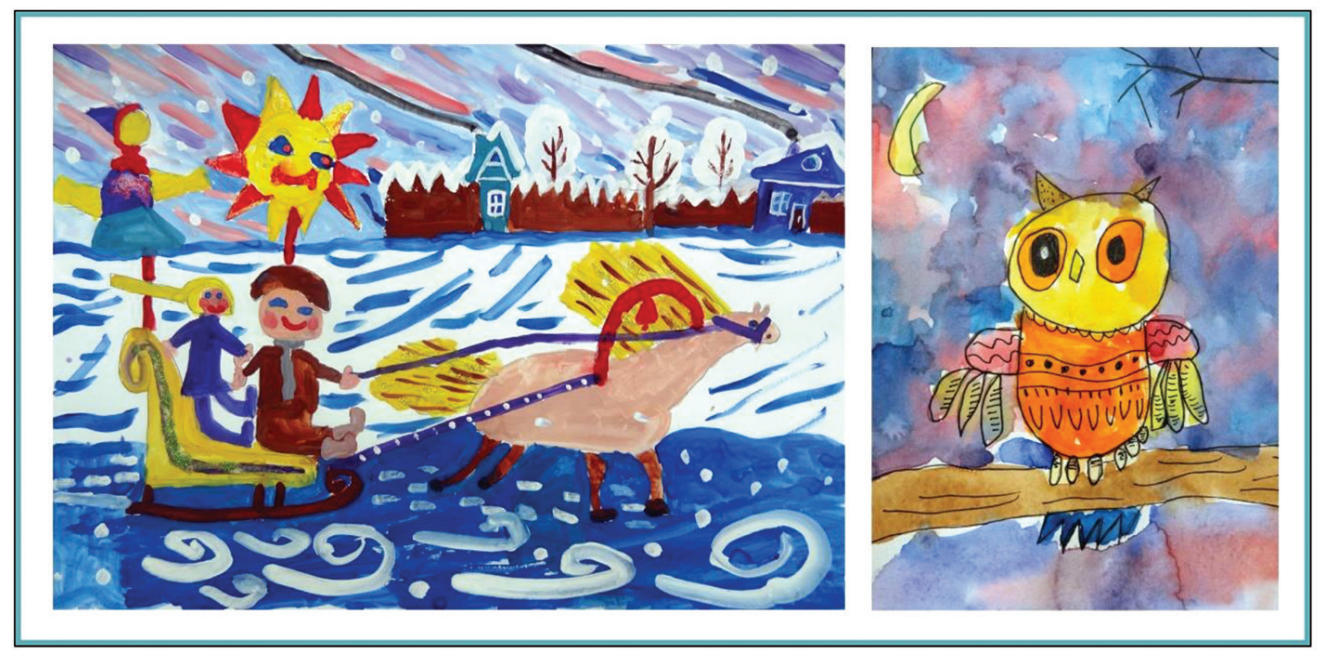

Figure 6. Creative works of children 5-6 years. Gouache, watercolor, pens.

The findings testify to the effectiveness of building work on aesthetic development based on the aesthetic paradigm of art.

\section{Results and Discussion}

With regard to the application of the paradigm, it should be noted that the club and project activities imply the greatest flexibility and variability of methods and techniques of work on aesthetic development, as well as the ability to implement an individual approach to each child. 
Thus, in the course of project activities based on the actual interests of children, it is possible to involve cultural and artistic workers, families of pupils, pupils of different ages and students, which significantly increases the cognitive activity of children. Circular activities enable the teacher to include in the lesson plan the most relevant topics, including those proposed by students. Circular and project activities also include a wide range of creative materials.

From early childhood age, children can use not only gouache, watercolor and colored pencils, but also coal, sanguine, sauce, wax crayons, gel pens, ink and other artistic materials. The aesthetic paradigm of art is applicable to the aesthetic development of people of different ages.

The components of the paradigm are filled with tasks appropriate to the age of the pupils. For example, for schoolchildren and students, the complexity of the tasks and the range of artistic materials are expanded by oil paints, acrylic and other artistic materials for creativity, depending on the chosen direction in art studies.

In view of the above, the created aesthetic paradigm of art has shown its effectiveness in work. Selected from rich methodological material and grouped into the paradigm the main components, such as cognitive component, practical component, culturological component, personality-oriented component, synergetic component, their interrelation, serve as a framework and help in organizing the educational process.

The application of the paradigm is possible both in planning the work of the Fine Arts Club and in organizing aesthetic development in an educational institution, such as an early childhood department of an educational complex. The filling of the components of the paradigm, as well as its framework, may vary depending on the program implemented in the educational institution.

\section{Conclusions}

The pilot activity carried out on the basis of the educational complex of Veshnyakovsky School, the Moscow State Budgetary Educational Institution on the introduction of a system of methodical measures of aesthetic orientation on the basis of the developed aesthetic paradigm of art, has proved its depth and efficiency. Children participating in the experiment have significantly improved the indicators of aesthetic development, including the aesthetic perception of art, artistic and creative development, verbal and non-verbal creativity. They showed good results in artistic and creative skills.

Thus, it has been scientifically and experimentally proved that the aesthetic paradigm of art has a positive impact on the formation of the person of the future who can be characterized with ethical and moral high ground, consciousness and the ability to create. The aesthetic paradigm of art is an effective tool for the aesthetic education of children. 
Using the aesthetic paradigm of art proposed by us in the organization of classes on the aesthetic development of students, selecting topics for activity and creativity, the teacher will be able, based on the accompanying system of an aesthetic paradigm of art, effectively and harmoniously build the entire teaching process to achieve an effective result in the study of art. In this way, making the process of aesthetic formation of the child's personality interesting.

\section{References}

Arnheim, R. (1974). Art and visual perception. Moscow: Progress.

Barb-gall, F. (2016). How to talk to children about art. RSUH-Moscow.

Burovkina, L. A. (2011). Scientific and methodological conditions of art education of students in institutions of additional education: monograph. Moscow: Moscow City University.

Dekhterev, B. A. (1972). Cognition of the world and illustration. Moscow: Children's literature.

Dubrovin, V. M. (2016). Education of schoolchildren. The Child in the Modern Cultural and Educational Space, 4, 68-80.

Dubrovin, V. M. (2016). Modern trends of fine, decorative and applied arts and design. Fundamentals of Creativity, 1, 18-22.

Elkonin, D. B. (1956). Mental development of a child from birth to entering school. Moscow: Psychology.

Gankina, E. Z. (1963). Russian artists of children's books. Moscow: Soviet artist.

Gerchuk, Yu. Ya. (2016). History of graphics and art books. Moscow: Aspect Press.

Ignatiev, E. I. (1961). Psychology of visual activity of children. Moscow: Uchpedgiz.

Ignatiev, S. E. (2007). Theory and practice of children's visual development. Moscow:

Moscow City University.

Komarova, T. S. (2015). Children in the world of creativity. Moscow: Mnemosina.

Konrad von Lange, (2016). Art education in the nursery. Saint-Petersburg: Aster-X.

Losev, A. F. (1963). History of ancient aesthetics (early classics). Moscow: Higher school.

Maklakov, A. G. (2002). General psychology. Saint-Petersburg: Piter.

Mayesky, M. (2009). Creative Activities for Young Children. (9th ed.). Cengage Learning Delmar. Clifton Park, NY.

Melik-Pashayev, A. A. (1982). Pedagogy of art and creative abilities. Moscow: Znanie.

Miroshkina, R. A. (1988). Preschool education. Formation of Expressiveness of an Image in Children's Drawings, 7, 27-31.

Nemensky, B. M. (1981). The wisdom of beauty: on the problems of aesthetic education. Book for teachers. Moscow: Enlightenment.

Ovsyannikov, M. F. (1984). History of aesthetic thought: a textbook. 2nd edition reprint. Moscow:

Higher school.

Rubinstein, S. L. (2015). Fundamentals of general psychology: in 2 vols. Saint-Petersburg: Piter. 
Semenova, M. A. (2011). Aesthetics of still life in watercolor painting. Elementary School Plus before and after: Monthly Scientific-Methodical and Psychological-Pedagogical Journal, 5 (11), 86-89.

Semenova, M. A. (2013). Watercolor. Aesthetic and pedagogical aspects: monograph. Moscow: Juventa.

Semenova, M. A. (2015). Aesthetics of watercolor painting in the preparation of future teachersartists. Moscow: Juventa.

Vaitkunas, G. (1967). Social aspects of the development of aesthetic thought in Lithuania (I9I91940): abstract. Vilnius.

Valikzhanina, S. V. (Ed.). (2018). Regional component in solving the problems of modern art education. Fine Art as a Source of Spiritual and Moral Education of the Younger Generation. Moscow: Moscow State Pedagogical University, 28-44.

Vygotsky, L. S. (2000). Psychology of art. Moscow: Azbuka.

Wenger, L. A. (2016). Perception and learning (Preschool age). Moscow: Enlightenment.

\title{
Estetinè meno paradigma ir jos poveikis vaiko asmenybès ateities formavimui
}

\author{
Semenova Maria Aleksandrovna ${ }^{1}$, Bykovskaya Maria Alexandrovna ${ }^{2}$ \\ Maskvos universitetas, Vtoroy Selskohoziajstvenny proezd 4-1, Maskva, Rusija, SemenovaMAL@mgpu.ru \\ 2 Maskvos universitetas, Vtoroy Selskohoziajstvenny proezd 4-1, Maskva, Rusija, Logrichka@yandex.ru
}

\section{Santrauka}

Autoriai nagrinėja vaiko asmenybės estetinio vystymosi problemą. Jie pagrindžia prioriteto ugdant šiuolaikinio žmogaus kultūrines, dvasines ir moralines bei estetines asmenybès savybes būtinumą.

Surinkta estetinio ugdymo metodinė medžiaga suteikia galimybę apibrèžti tyrimo problemą: kokios yra pedagoginès efektyvumo sąlygos vaiko estetiniam ugdymui per meną? Straipsnyje pristatoma sukurta estetinè meno paradigma ugdymo procese bei dalijamasi eksperimentinio darbo patirtimi.

Pasakojama apie efektyvų pasirengimą ir jo svarbą vaiko estetiniam ugdymui mokymosi procese. Šis tyrimas apemė teorinès medžiagos ir dokumentų rinkimą apie ikimokyklinio amžiaus vaikų estetinị meninị ugdymą; stebejjimus švietimo organizacijose; lygio nustatymą ir kriterijų sudarymą. Straipsnyje atskleidžiami ir trumpai apibūdinami paradigmos struktūriniai elementai bei aprašomos praktinès estetinès meno paradigmos efektyvumo sąlygos. Remdamiesi savo darbo rezultatais ir metodinès literatūros analize bei plačiausiai naudojamomis bendrojo ugdymo 
programomis, autoriai sukūrè estetinę meno paradigmą ir apibrèžè pagrindinius paradigmos komponentus: pažintinị komponentą, praktinị komponentą, kultūrologinị komponentą, i asmenybę orientuotą komponentą ir sinergetinị komponentą. Straipsnyje pristatomas Maskvos edukaciniame komplekse atliktas tyrimas, apimantis vaikų estetinio ugdymo praktikos stebẻjimus, estetinio suvokimo ir meninio kūrybiškumo pasiekimų kriterijų lygio grupes, teorinès medžiagos analizę bei estetinio ugdymo menu (pavyzdžiui, ikimokyklinio amžiaus vaikų estetinio vystymosi knygų iliustracijų erdvèje paradigma) metodinius patikslinimus.

Eksperimente dalyvę vaikai žymiai pagerino savo estetinio vystymosi rodiklius, tokius kaip estetinis meno suvokimas, meninis ir kūrybinis tobulejimas, verbalinis ir neverbalinis kūrybiškumas. Tyrimas atskleidžia, kad estetinė meno paradigma daro teigiamą poveikị asmens, kuriam reikalingas aukštas etinis ir moralinis lygis, sąmoningumas ir gebejjimas kurti, ateities formavimui. Mokytojas, pasirinkdamas veiklos ir kūrybiškumo temas, remdamasis estetine meno paradigma, gali sukurti efektyvią ir harmoningą mokymosi aplinką bei padaryti vaiko asmenybès estetinio formavimo procesą įdomų patiems mokiniams.

Esminiai žodžiai: estetinis vystymasis, meninis kūrybiškumas, estetinè meno paradigma, edukacines veiklos.

Gauta 20191208 / Received 08122020

Priimta 20200506 / Accepted 06052020 